\title{
Effects of Peer-Based Intervention on Prevention Behavior of Sexually Transmitted Infections and Unwanted Pregnancy in Adolescents: A Meta Analysis
}

\author{
Denanda Agnes Safitri'), Setyo Sri Rahardjo²), Bhisma Murti') \\ 1)Masters Program in Public Health, Universitas Sebelas Maret \\ 2)Faculty of Medicine, Universitas Sebelas Maret
}

\section{ABSTRACT}

Background:In facing the transition period, many adolescents tend to explore their sexuality and engage in risky sexual behavior. This risky behavior is a main contributor to sexually transmitted infections (STIs) and unintended pregnancy. Peer-based intervention is often used in programs that promote sexual and reproductive health in adolescents, including prevention of STIs and unintended pregnancy. This study aimed to examine the effect of peerbased interventin on STI and unintended pregnancy preventive behavior among adolescents.

Subjects and Method:This was a meta-analysis study that was carried out according to the PRISMA guidelines. The articles with randomized controlled trial study designs published in 2000-2020 were included for the metaanalysis. Several databases were used in searching for the articles. The articles obtained were screened to obtain the articles that met the eligibility criteria. The articles were analyzed using RevMan 5.4.
Results:There were 14 articles that met the criteria for a meta-analysis with a sample size of 18,325 . The study showed that peer-based intervention was statistically significant in improving sexually transmitted infection preventive behavior $(\mathrm{RR}=1.15 ; 95 \% \mathrm{CI}=1.02$ to 1.30; $\mathrm{p}=0.020$ ) and unintended pregnancy preventive behavior among adolescents $(R R=1.14$; $95 \% \mathrm{CI}=1.00$ to $1.30 ; \mathrm{p}=0.040$ ).

Conclusion:Peer-based intervention should be considered as an effort to promote STIs and unintended pregnancy preventive behavior among adolescents.

Keywords: peer-based intervention, sexually transmitted infection, unintended pregnancy

\section{Correspondence:}

Denanda Agnes Safitri. Masters Program in Public Health, Universitas Sebelas Maret. Jl. Ir. Sutami 36A, Surakarta 57126, Central Java. Email: denandagnesafitri@gmail.com

\section{Cite this as:}

Safitri DA, Rahardjo SS, Murti B (2020). Effects of Peer-Based Intervention on Prevention Behavior of Sexually Transmitted Infections and Unwanted Pregnancy in Adolescents: A Meta Analysis. J Matern Child Health. 05(06): 693-704. https://doi.org/10.26911/thejmch.2020.05.06.09.

c(i) (ㅇ) Journal of Maternal and Child Health is licensed under a Creative Commons Attribution-NonCommercial-ShareAlike 4.o International License.

\section{BACKGROUND}

The transition period among adolescents causes them to start exploring their sexuality and engaging in risky sexual behavior. This is the main contributor to sexually transmitted infections (STIs) and unintended pregnancy (Maria et al., 2017; Masa et al., 2019).

UNICEF (2012) stated that \pm 2.2 million adolescents in the world were infected with HIV. In addition, in the United States, half of all new STI cases $( \pm 20$ million cases/year) occurred in adolescents aged 15-24 years (Maria et al., 2017). In 2018, the CDC reported more than $20 \%$ of new HIV cases occurred in adolescents aged 1324 years. The dominant STI cases were chlamydia, gonorrhea, and syphilis (Peskin et al., 2019; Wesche et al., 2019). 
Besides, another serious problem for adolescents is unintended pregnancy. Oman et al. (2018) stated that at least 1 in 3 American girls who lived in foster families have had pregnancy at the age of 17-19 years. In addition, $18 \%$ of teenage boys were at high risk of getting someone pregnant. Most of these pregnancies were unwanted pregnancies. The uninteded pregnancy in adolescents caused abortion. In Spain, the highest incidence of abortion was in women aged 20-24 years (García-Vázquez et al., 2019).

Intervention is needed to minimize the problems occur. Peer education is often used in programs that promote adolescent sexual and reproductive health. Information delivery is considered successful due to the social effect of peer groups which has a strong impact on adolescents (Maley \& Eckenrode, 2017; Raidoo \& Kaneshiro, 2017). Peer education helps adolescents feel emotional security, self-esteem, and selfconfidence, and provides opportunities for problems without feeling awkward (Mezey et al., 2015).

Based on the high incidence of sexually transmitted infections (STIs) and unintended pregnancy among adolescents and the need for appropriate treatment, the researchers were interested in conducting a meta-analysis to examine the effectiveness of peer-based intervention on STI and unintended pregnancy preventive behavior among adolescents based on the previous primary study.

\section{SUBJECTS AND METHOD}

\section{Study Design}

This study was a meta-analysis of primary studies published between 2000-2020. The databases involved in searching for articles were: PubMed, Science Direct, Research Gate, and Google Scholar. The keywords were "peer education" OR "peer led" OR "peer counseling” OR "peer approach" OR "peer teaching” OR "peer mentoring" AND "sexually transmitted diseases" OR "sexually transmitted infections" OR "unwanted pregnancy" OR "unintended pregnancy" AND adolescent AND "randomized controlled trial".

The extraction for the articles was carried out based on PRISMA 2009 Flow Diagram. After the final result of the article extraction, there was an assessment of the quality of the study using an 8-item-scale plus 1 item regarding the sample size $(>100)$. Each assessment criterion was given 1 score (one) if 'yes' and o (zero) if 'no'.

\section{Inclusion Criteria}

The articles were included if: (1) they were full paper article with RCT design, (2) Single or double blind, (3) the intervention given was about sexual education of peerbased intervention with comparator of nonpeer-based intervention, (4) the study subjects aged 10 -24 years, (5) the outcomes was sexually transmitted infections and or unintended pregnancy preventive behavior.

\section{Exclusion Criteria}

The researchers excluded the articles of the primary study if they were not full text, published before 2000, and published in non-English language.

\section{Operational Definition of Variables} Peer-based intervention was an educational intervention that involved someone from the peer group as a teacher to share information on sexual and reproductive health that supported healthy decision making among adolescents.

STI preventive behavior was an outcome after peer-based sexual and reproductive health education interventions in the form of actions conducted by adolescents to prevent STIs. It could be the condom use behavior, the behavior of having safe vaginal sexual intercourse, and substance riskrelated behavior. 
Safitri et al./ Peer-Based Intervention on Prevention Behavior of Unwanted Pregnancy

Unintended pregnancy preventive behavior was an outcome after peer-based sexual and reproductive health education interventions in the form of actions conducted by adolescents to prevent unintended pregnancies. it could be the condom use or the use of hormonal contraceptives.

\section{Data Analysis}

This study used RevMan 5.4 in the metaanalysis to determine the combined effect

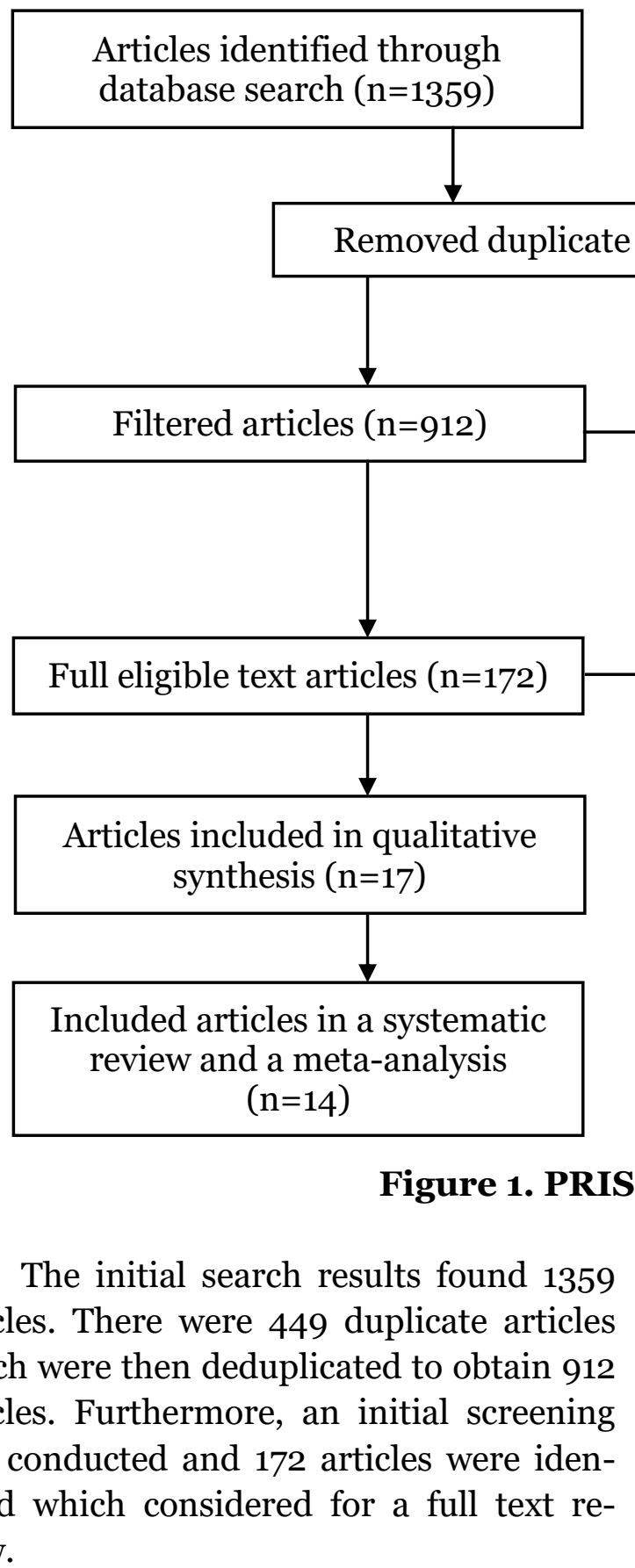

of the result of the primary study of eligible RCTs. This study used a random effect model to analyze the data.

\section{RESULTS}

The articles were obtained from multiple databases with unique keyword combinations by the researchers. The article review process can be seen in Figure 1.

Addition of articles identified from other searches $(n=2)$
Published articles $(\mathrm{n}=740)$

1. The title was irrelevant (187)

2. Not original article (215)

3. Non RCT (266)

4. Not in English (19)

5. Book or book chapter (53)
1. Full-text of published articles $(n=155)$

2. Inappropriate intervension (51)

3. Incorrect outcome (64)

4. Incorrect population (40)
155 articles were excluded because the intervention studied was not peer-based intervention, the outcome was not STI and unintended pregnancy preventive behavior, and the study population was incorrect. In the final result of the article extraction, 14 articles met the requirements. 
Safitri et al./ Peer-Based Intervention on Prevention Behavior of Unwanted Pregnancy

Table 1. The assessment of the Study Quality

\begin{tabular}{|c|c|c|c|c|c|c|c|c|c|c|}
\hline Publication & Cohort & $\begin{array}{c}\text { With } \\
\text { control } \\
\text { group }\end{array}$ & $\begin{array}{c}\text { Pre/post } \\
\text { intervention }\end{array}$ & $\begin{array}{c}\text { Random } \\
\text { assignment }\end{array}$ & $\begin{array}{c}\text { Random } \\
\text { selection for } \\
\text { assessment }\end{array}$ & $\begin{array}{c}\text { Sample } \\
\text { size } \\
(>100)\end{array}$ & $\begin{array}{l}\text { Follow } \\
\text { up rate } \\
\geq 80 \%\end{array}$ & $\begin{array}{c}\text { Comparable } \\
\text { sociodemographic } \\
\text { between study arms }\end{array}$ & $\begin{array}{c}\text { Comparable baseline } \\
\text { outcome measures } \\
\text { between study arms }\end{array}$ & Total \\
\hline $\begin{array}{l}\text { (Bonell et al., } \\
\text { 2013) }\end{array}$ & 1 & 1 & 1 & 1 & (1) & 1 & 1 & (2) & (1) & 9 \\
\hline $\begin{array}{l}\text { (Garfein et } \\
\text { al., 2007) } \\
\text { (Giménez- }\end{array}$ & 1 & 1 & 1 & 1 & 1 & 1 & o & 1 & 1 & 8 \\
\hline $\begin{array}{l}\text { García et al., } \\
\text { 2018) }\end{array}$ & 1 & 1 & 1 & 1 & 1 & 1 & 1 & 1 & 1 & 9 \\
\hline $\begin{array}{l}\text { (Ibrahim } \\
\text { al., 2012) }\end{array}$ & 1 & 1 & 1 & 1 & 1 & 1 & 1 & o & 1 & 8 \\
\hline $\begin{array}{l}\text { (Kelly et al., } \\
2007 \text { ) }\end{array}$ & 1 & 1 & 1 & 1 & 1 & 1 & 1 & 1 & 1 & 9 \\
\hline $\begin{array}{l}\text { (Kemigisha et } \\
\text { al., 2019) }\end{array}$ & 1 & 1 & 1 & 1 & 1 & 1 & o & 1 & 1 & 8 \\
\hline $\begin{array}{l}\text { (Morales et } \\
\text { al., 2015) }\end{array}$ & 1 & 1 & 1 & 1 & 1 & 1 & o & 1 & 1 & 9 \\
\hline $\begin{array}{l}\text { (Okonofua et } \\
\text { al., 2003) }\end{array}$ & 1 & 1 & 1 & 1 & 1 & 1 & 1 & 1 & 1 & 9 \\
\hline $\begin{array}{l}\text { (Sherman et } \\
\text { al., 2009) }\end{array}$ & 1 & 1 & 1 & 1 & 1 & 1 & 1 & 1 & 1 & 9 \\
\hline $\begin{array}{l}\text { (Sieving et al., } \\
\text { 2011) }\end{array}$ & 1 & 1 & 1 & 1 & 1 & 1 & 1 & o & 1 & 8 \\
\hline $\begin{array}{l}\text { (Sieving et al., } \\
\text { 2013) }\end{array}$ & 1 & 1 & 1 & 1 & 1 & 1 & 1 & o & 1 & 8 \\
\hline $\begin{array}{l}\text { (Sieving et al., } \\
\text { 2014) }\end{array}$ & 1 & 1 & 1 & 1 & 1 & 1 & 1 & o & 1 & 8 \\
\hline $\begin{array}{ll}\text { (Strange } & \text { et } \\
\text { al., 2006) }\end{array}$ & 1 & 1 & 1 & 1 & 1 & 1 & 1 & 1 & 1 & 9 \\
\hline $\begin{array}{l}\text { (Tobin et al., } \\
\text { 2011) }\end{array}$ & 1 & 1 & 1 & 1 & 1 & 1 & 1 & 1 & 1 & 9 \\
\hline
\end{tabular}


Safitri et al./ Peer-Based Intervention on Prevention Behavior of Unwanted Pregnancy

Fourteen articles were primary studies of RCTs conducted in Asia, Europe, America, and Africa. There were 2 articles of primary studies conducted in Asia: articles from Malaysia and Thailand. There were 4 studies in Europe. 2 studies came from England and another 2 studies came from Spain. Besides, 6 articles of primary study came from the United States. 2 studies came from the African continent, one from Uganda and one from Nigeria. After that, the researcher conducted an assessment of the quality of the study (Table 1).

1. The meta-analysis of the effect of peer-based intervention on STI preventive behavior.

There were 13 articles examining the effect of peer-based intervention on STI preven- tive behavior (articles No.1, 2, 3, 4, 5, 6, 7, $8,9,10,12,13,14)$. The summary sources related to the study were in Table 2.

The forest plot in Figure 2 shows that peer-based intervention was able to increase STI preventive behavior in adolescents 1.15 times better than non peer-based intervention. These results were statistically significant $(\mathrm{RR}=1.15 ; 95 \% \mathrm{CI}=1.02$ to 1.30 ; $\mathrm{p}=0.020)$. The Random Effect Model was used due to high heterogeneity $\left(\mathrm{I}^{2}=84 \%\right.$; $\mathrm{p}$ $<0.00001)$.

In Figure 3, the funnel plot shows the asymmetry of shape. There is 1 plot on the left side away from the vertical center line. This indicates a publication bias.

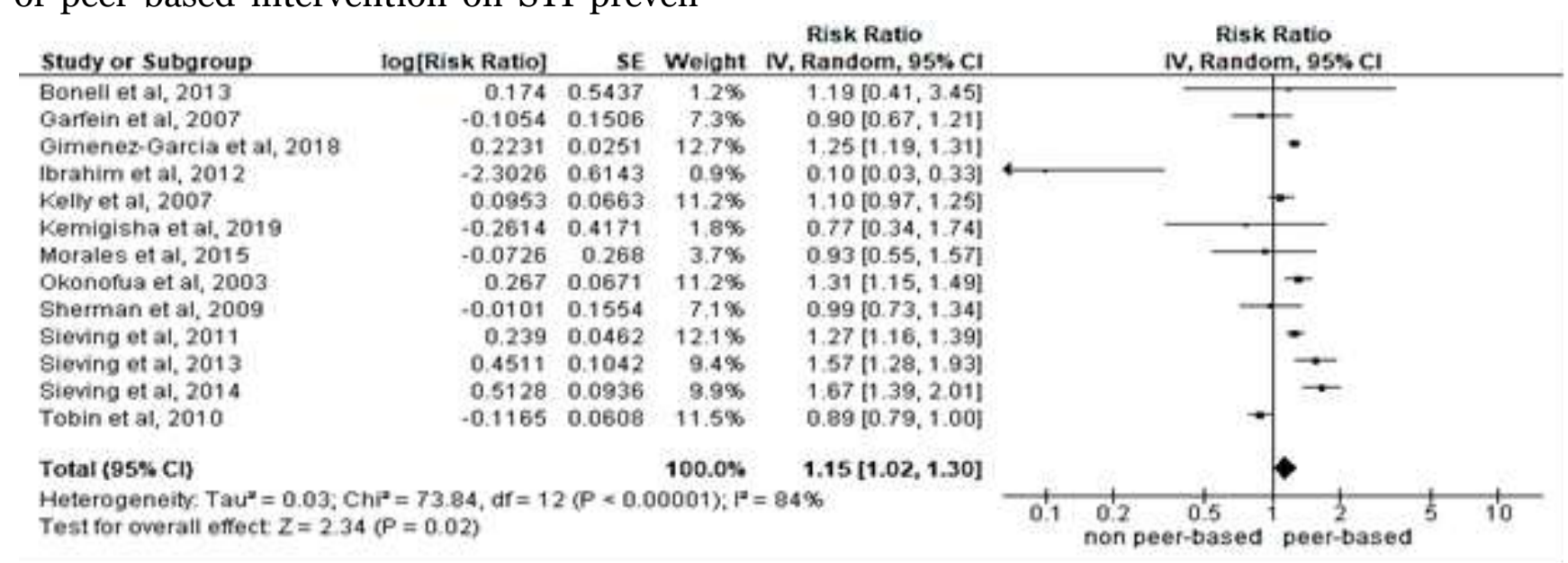

Figure 2. The Forest Plot of Peer-based Intervention on Sexually Transmitted Infection (STI) Preventive Behavior

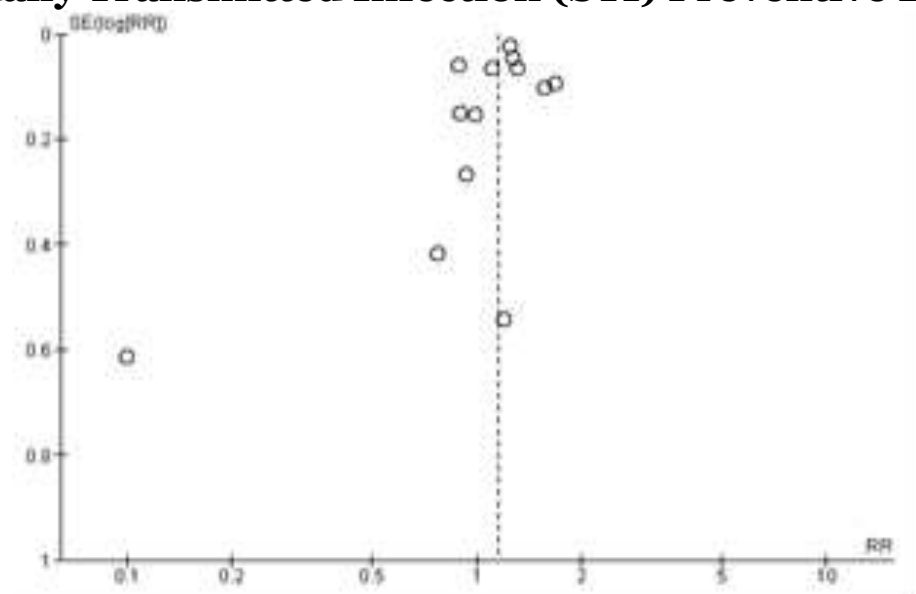

Figure 3. The Funnel Plot of Peer-Based Intervention on Sexually Transmitted Infection (STI) Preventive Behavior 
Table 2. Summary source

\begin{tabular}{|c|c|c|c|c|c|c|}
\hline \multirow{2}{*}{ Author, year } & \multirow{2}{*}{ Location } & \multirow{2}{*}{$\begin{array}{l}\text { Sample } \\
\text { Size }\end{array}$} & \multirow{2}{*}{ Intervension (I) and Comparator (C) } & \multirow{2}{*}{ Outcome } & \multicolumn{2}{|c|}{ Effect } \\
\hline & & & & & OR (95\% CI) & RR (95\% CI) \\
\hline (Bonell et al., 2013) & England & 449 & $\begin{array}{l}\text { I: peer-led sex education with T\&T method } \\
\text { C: non peer-based intervention }\end{array}$ & Condom use & $1.2(0.4-3.1)$ & $1.19(0.41-3.45)$ \\
\hline (Sieving et al., 2011) & United States & 253 & $\begin{array}{l}\text { I: peer-based intervention with Prime Time } \\
\text { program } \\
\text { C: non peer-based intervention }\end{array}$ & Condom use & $1.45(1.26-1.67)$ & $1.27(1.16-1.38)$ \\
\hline (Sieving et al., 2013) & United States & 253 & $\begin{array}{l}\text { I: peer-based intervention with Prime Time } \\
\text { program } \\
\text { C: non peer-based intervention }\end{array}$ & Condom use & - & $1.57(1.28-1.93)$ \\
\hline (Sieving et al., 2014) & United States & 253 & $\begin{array}{l}\text { I: peer-based intervention with Prime Time } \\
\text { program } \\
\text { C: non peer-based intervention }\end{array}$ & Condom use & - & $1.67(1.39-2.01)$ \\
\hline $\begin{array}{l}\text { (Kemigisha et al., } \\
\text { 2019) }\end{array}$ & Uganda & 1096 & $\begin{array}{l}\text { I: peer-based intervention } \\
\text { C: non peer-based intervention }\end{array}$ & Condom use & $\begin{array}{l}0.76(0.32- \\
1.80)\end{array}$ & $0.77(0.34-1.73)$ \\
\hline (Ibrahim et al., 2012) & Malaysia & 276 & $\begin{array}{l}\text { I: peer-based HIV education intervention } \\
\text { C: non peer-based HIV education }\end{array}$ & $\begin{array}{l}\text { Substance risk } \\
\text { behavior }\end{array}$ & $\begin{array}{l}0.07(0.02 \\
0.34)\end{array}$ & $0.10(0.03-0.34)$ \\
\hline (Morales et al., 2016) & Spain & 1563 & $\begin{array}{l}\text { I: peer-based intervention } \\
\text { C: non peer-based intervention }\end{array}$ & Condom use & $\begin{array}{l}0.87(0.38 \\
2.09)\end{array}$ & $0.93\left(0.55^{-1.57)}\right.$ \\
\hline $\begin{array}{l}\text { (Giménez-García et al., } \\
\text { 2018) }\end{array}$ & Spain & 225 & $\begin{array}{l}\text { I: peer-led HIV education intervention } \\
\text { C: non peer-based HIV education intervention }\end{array}$ & Safe vaginal sex & $\begin{array}{l}3.33(2.21 \\
5.05)\end{array}$ & $1.25(1.19-1.33)$ \\
\hline (Garfein et al., 2007) & United States & 854 & $\begin{array}{l}\text { I: peer-led HIV-HCV education } \\
\text { C: non peer-led HIV-HCV education }\end{array}$ & Condom use & - 5 & $0.90(0.67,1.21)$ \\
\hline (Sherman et al., 2009) & Thailand & 983 & $\begin{array}{l}\text { I: peer-based STIs education intervention } \\
\text { C: non peer-based STIs education intervention }\end{array}$ & Condom use & $0.98(0.61-1.57)$ & $0.99(0.73-1.34)$ \\
\hline (Strange et al., 2006) & England & 9508 & $\begin{array}{l}\text { I: peer-based sex education intervention } \\
\text { C: non peer-based intervention }\end{array}$ & $\begin{array}{l}\text { Contraception } \\
\text { use }\end{array}$ & $\begin{array}{l}0.85\left(0.55^{-}\right. \\
1.34)\end{array}$ & $0.976(0.90-1.036)$ \\
\hline (Tobin et al., 2011) & United States & 227 & $\begin{array}{l}\text { I: peer-based STIs education } \\
\text { C: non peer-led STIs education }\end{array}$ & Condom use & $\begin{array}{l}0.61(0.42- \\
0.89)\end{array}$ & $0.89(0.79-1.00)$ \\
\hline (Kelly et al., 2007) & $\begin{array}{l}\text { Amerika } \\
\text { Serikat }\end{array}$ & 527 & $\begin{array}{l}\text { I: peer-based intervention } \\
\text { C: non peer-based education }\end{array}$ & Condom use & $\begin{array}{l}0.149(0.89- \\
2.24)\end{array}$ & $1.10(0.97-1.25)$ \\
\hline $\begin{array}{l}\text { (Okonofua et al., } \\
\text { 2003) }\end{array}$ & Nigeria & 1858 & $\begin{array}{l}\text { I: peer-based STDs education intervention } \\
\text { C: non peer-based STDs education }\end{array}$ & Condom use & $1.50(1.22-1.79)$ & $1.31(1.15-1.49)$ \\
\hline
\end{tabular}


Safitri et al./ Peer-Based Intervention on Prevention Behavior of Unwanted Pregnancy

2. The meta-analysis of the effect of peer-based intervention on unwanted pregnancy preventive behavior.

Twelve articles examining the effect of a peer-based intervention on unintended pregnancy preventive behavior (articles No.1, 2, 3, 4, 5, 7, 9, 10, 11, 12, 13, 14). The summary sources related to the study are shown in Table 2.

The forest plot in Figure 4 shows that peer-based intervention was 1.14 times better than non-peer-based intervention in increasing unintended pregnancy preventive behavior and the result was statistically significant (RR 1.14; 95\% CI=1.00 to 1.30 ; $\mathrm{p}=0.040)$. Besides, there was high heterogeneity between experiments $\left(\mathrm{I}^{2}=84 \%\right.$; $\mathrm{p}<0.00001)$. Therefore, it used the Random Effect Model.

The Funnel plot in Figure 5 indicates no publication bias. There was a symmetrical plot on both sides. In addition, it formed an inverted funnel.

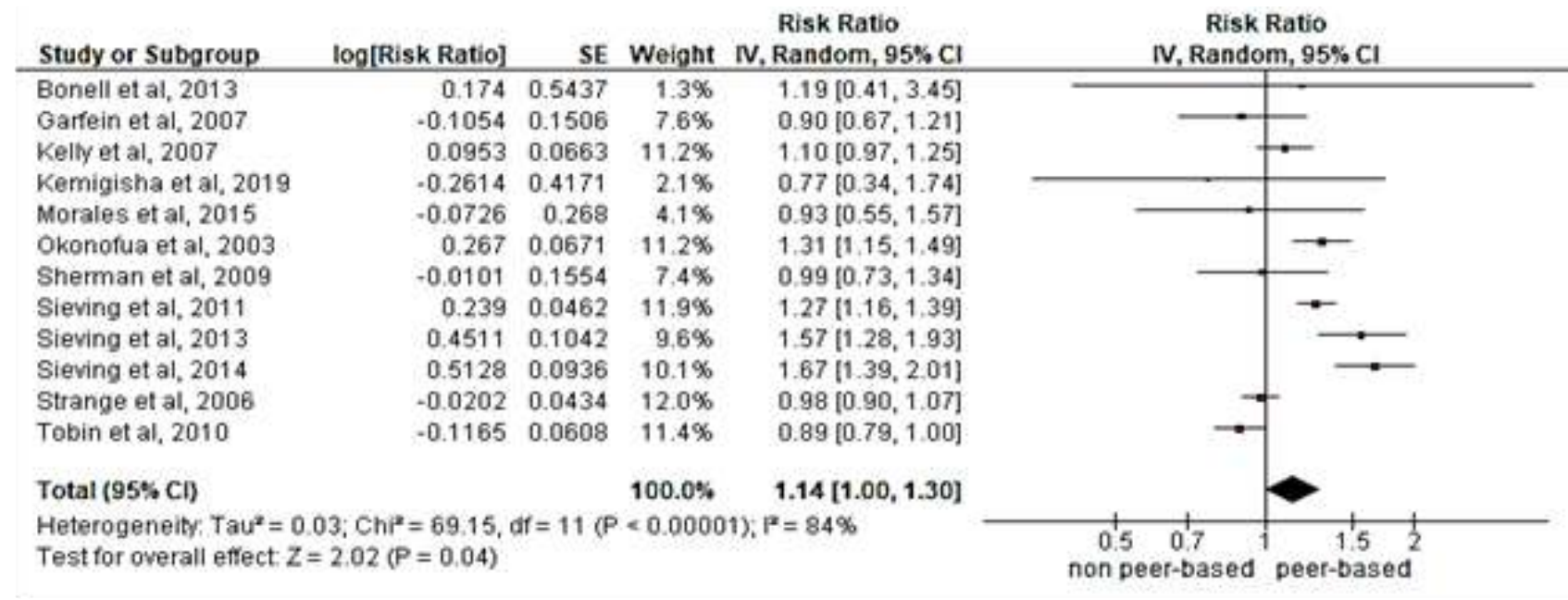

Figure 4. The Forest Plot of Peer-Based Intervention on Unwanted Pregnancy Preventive Behavior

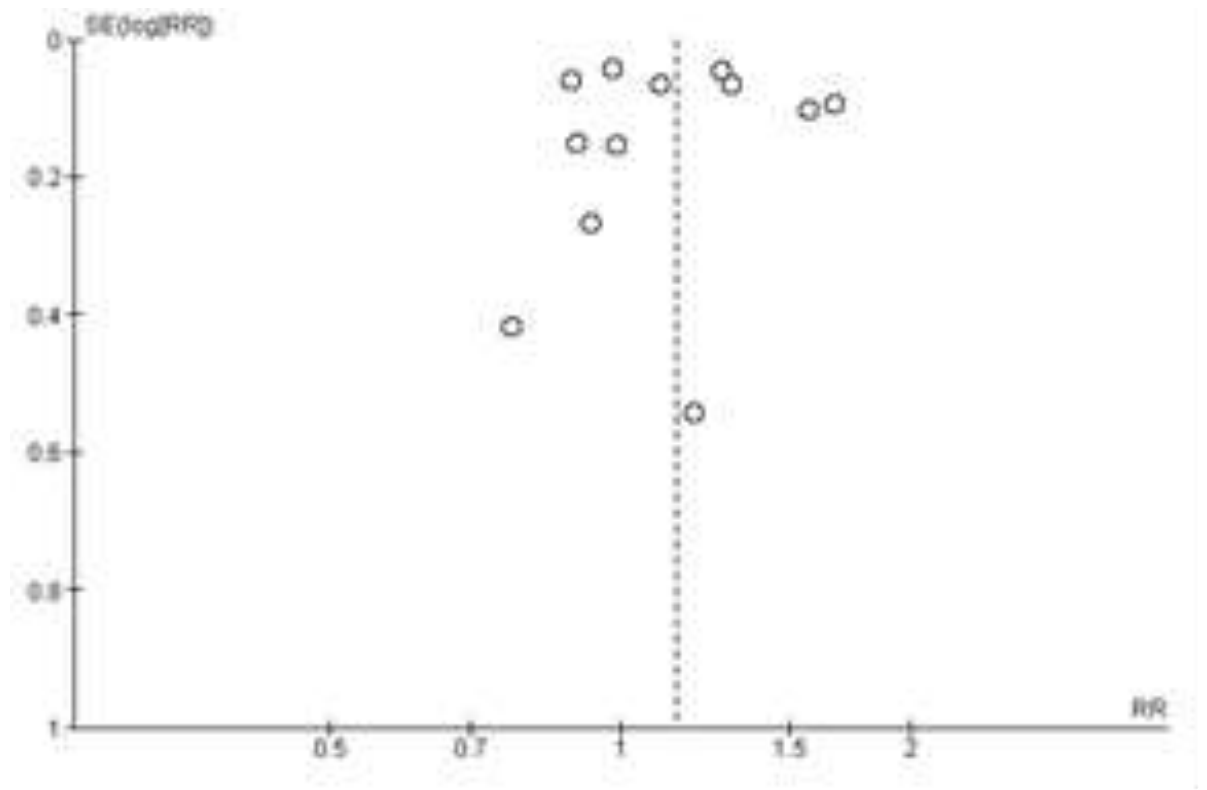

Figure 5. The Funnel Plot of Peer-Based Intervention on Unwanted Pregnancy Preventive Behavior 


\section{DISCUSSION}

There were 14 articles with a sample size of 18.325. From all articles, 3 articles used RR as the statistical outcome. Based on the data analysis, the researchers considered converting OR to RR. The OR calculation was converted into RR using http://www.clincalc.com/Stats/ConvertOR.aspx

Based on the results of the metaanalysis, peer-based intervention was 1.15 times better in improving sexually transmitted infection preventive behavior in adolescents. These results were statistically significant (RR 1.15; 95\%CI=1.02 to 1.30 ; $\mathrm{p}=0.020)$.

This result is in line with a study conducted by Calloway et al. (2014) that peer education that focused on the components of the Health Belief Model, skill-building, and peer effect was an effective strategy in reducing risky behavior of having STI. This is in line with a study conducted by Bulduk \&Erdogan (2012) and Mmbaga et al. (2017) that peer education had a significant effect on delaying sexual initiation and condom use behavior by adolescents who participated in peer education.

The findings of this study are in line with the study conducted by Saad et al (2012) that risky sexual behavior by adolescents decreased steadily in the intervention group. The effectiveness of sexual education interventions depended on the teaching method. Therefore, peer-based intervention had succeeded in reducing risky sexual behavior in adolescents.

This is confirmed by Adeomi et al. (2014) that the effectiveness of peer education in adolescents occurred due to adequate training and supportive supervision. Peer involvement could increase youth skills and awareness of STI preventive efforts. In peer education, there was a peer effect that became one of the determining factors for adolescents to carry out a behavior.

In addition, to prevent unintended pregnancy, peer-based intervention could increase unintended pregnancy preventive behavior in adolescents 1.14 times better than non-peer-based intervention and statistically significant ( $\mathrm{RR} 1.14 ; 95 \% \mathrm{CI}=1.00$ to $1.30 ; \mathrm{p}=0.040$ ).

The ability of peer-based intervention in increasing unintended pregnancy preventive behavior is supported by a study conducted by Stephenson et al (2008) that peer-based intervention was worthy to be considered as a strategy to prevent unintended pregnancy in adolescents. Adolescent girls who received education about sexual and reproductive health with a peer education approach were more likely to report condom use. In addition, a study conducted by Calise et al (2016) described a decrease in the prevalence of unsafe vaginal sex in adolescent girls after participating in peerbased sexual and reproductive health education interventions.

Harrison et al (2016) emphasized that consistent condom use was the right effort for adolescents to anticipate unintended pregnancies. However, he found no significant difference in condom use in the intervention group and the control group after peer-based intervention. This supported the findings in the authors' meta-analysis that there was low power of the influence of peer-based intervention on unintended pregnancy preventive behavior in adolescents.

Sarnquist et al (2016) explained that the low power of influence $(1.00 \leq R R \leq 1.50)$ on the effectiveness of peer-based intervention could occur due to the fact that pregnancy in adolescents was a complex problem. A series of factors related to this were poverty, gender bias, and inadequate access to education. Therefore, the best way to 
promote unintended pregnancy prevention behavior in adolescents was by providing educational interventions that were in line with the provision of a comprehensive range of services.

Considering that the results of the meta-analysis of this study were in line with several studies, conducting peer-based intervention as a strategy in promoting healthy behavior related to STIs and unintended pregnancy was worth considering.

The limitation of this study was that the researchers excluded the studies that were not written in English. This allowed for bias and reduced the precision of the combined estimation of the effects of the intervention. In addition, the researchers used 4 databases only to search for primary studies. The next researchersare expected to expand the search by adding other databases besides the database of the researchers used in this study.

\section{AUTHOR CONTRIBUTION}

Conceptualization: Denanda Agnes Safitri, Setyo Sri Rahardjo, Bhisma Murti

Data curation: Bhisma Murti, Setyo Sri Rahardjo

Data analysis: Denanda Agnes Safitri

Writing - original draft: Denanda Agnes Safitri

Writing - review \& editing: Denanda Agnes Safitri, Setyo Sri Rahardjo, Bhisma Murti

\section{CONFLICT OF INTEREST}

The researchers stated that there was no financial relationship or commercial purpose that could create a conflict of interest.

\section{FUNDING AND SPONSORSHIP}

Nil or None

\section{ACKNOWLEDGEMENT}

We would like to thank the Masters Program in Public Health, Sebelas Maret Uni- versity, for the support in the publication of this manuscript. The contents of this manuscript were entirely the responsibility of the author.

\section{REFERENCE}

Adeomi AA, Adeoye OA, Asekun-Olarinmoye EO, Abodunrin OL, OlugbengaBello AI, Sabageh AO (2014). Evaluation of the effectiveness of peer education in improving HIV knowledge, attitude, and sexual behaviours among in-school adolescents in osun state, Nigeria. AIDS Res Treat. 2014: 131756. https://doi.org/10.1155/2014$/ 131756$.

Bonell C, Maisey R, Speight S, Purdon S, Keogh P, Wollny I, Sorhaindo A, et al. (2013). Randomized controlled trial of "teens and toddlers": A teenage pregnancy prevention intervention combining youth development and voluntary service in a nursery. $\mathrm{J}$ Adolesc. 36(5):859-70. https://doi.org/10.1016/j.adolescence.2013.07.005.

Bulduk S, Erdogan S (2012). The effects of peer education on reduction of the HIV/sexually transmitted infection risk behaviors among Turkish University students. J Assoc Nurses AIDS Care. 23(3): 233-243. https://doi.org/10.1016/j.jana.2011.02.003.

Calise TV, Chow W, Dore KF, O'Brien MJ, Heitz ER, Millock RR (2016). Healthy futures program and adolescent sexual behaviors in 3 Massachusetts cities: A randomized controlled trial. Am J Public Health. 106(S1): S103-S109 https://doi.org/10.2105/AJPH.2016.303389.

Calloway DS, Long-White DN, Corbin DE (2014). Reducing the Risk of HIV/AIDS in African American College Students: An Exploratory Investigation of the Efficacy of a Peer Educator Ap- 
Safitri et al./ Peer-Based Intervention on Prevention Behavior of Unwanted Pregnancy

proach. Health Promot Pract. 15(2): 181-188. https://doi.org/10.1177/1524839913504757.

Espada JP, Morales A, Orgilés M, Jemmott JB, Jemmott LS (2015). Short-term evaluation of a skill-development sexual education program for spanish adolescents compared with a wellestablished program. J Adolesc Health. 56(1): 30-37. https://doi.org/10.1016/j.jadohealth.2014.08.018.

García-Vázquez J, Quintó L, Agulló-Tomás $\mathrm{E}$ (2019). Impact of a sex education programme in terms of knowledge, attitudes and sexual behaviour among adolescents in Asturias (Spain). Glob Health Promot. 27(3): 122-130. https://doi.org/10.1177/1757975919873621.

Garfein RS, Golub ET, Greenberg AE, Hagan H, Hanson DL, Hudson SM, Kapadia F, et al. (2007). A peer-education intervention to reduce injection risk behaviors for HIV and hepatitis $\mathrm{C}$ virus infection in young injection drug users. AIDS. 21(14): 1923-1932. Retrieved from https://journals.lww.com/aidsonline/fulltext/2007/09120 /a_peer_education_intervention_to_ reduce_injection.12.aspx.

Giménez-García C, Ballester-Arnal R, GilLlario MD, Salmerón-Sánchez $P$ (2018). Peer-led or expert-led intervention in HIV prevention efficacy? A randomized control trial among Spanish young people to evaluate their role. Health Promot Pract. 19(2): 277-286. https://doi.org/10.1177/1524839917733966.

Harrison A, Hoffman S, Mantell JE, Smit JA, Leu CS, Exner TM, Stein ZA (2016). Gender-focused HIV and pregnancy prevention for schoolgoing adolescents: The Mpondombili pilot intervention in KwaZulu-Natal,
South Africa. J HIV AIDS Soc Serv. 15(1): 29-47. https://doi.org/10.108o/15381501.2014.999183.

Ibrahim N, Rampal L, Jamil Z, Zain AM (2012). Effectiveness of peer-led education on knowledge, attitude and risk behavior practices related to HIV among students at a Malaysian public university A randomized controlled trial. Prev Med, 55(5): 505-510. https://doi.org/10.1016/j.ypmed.2012.09.003.

Kelly PJ, Owen SV, Peralez-Dieckmann E, Martinez E (2007). Health Interventions With Girls in the Juvenile Justice System. Women's Health Issues, 17(4): 227-236. https://doi.org/10.1016/j.whi.2007.03.005.

Kemigisha E, Bruce K, Ivanova O, Leye E, Coene G, Ruzaaza GN, Ninsiima AB, et al. (2019). Evaluation of a school based comprehensive sexuality education program among very young adolescents in rural Uganda. BMC Public Health, 19(1). https://doi.org/10.1186/s12889-019-7805-y.

Maria SD, Guilamo-Ramos V, Jemmott LS, Derouin A, Villarruel A (2017). Nurses on the front lines: Improving adolescent sexual and reproductive health across health care settings. Am J Nurs. 117(1): 42-51. https://doi.org/10.1097/01.NAJ.ooo0511566.12446.45.

Maley M, Eckenrode J (2017). Systematic translational review peer education for adolescent reproductive and sexual health. 2008. Retrieved from https://www.bctr.cornell.edu/wpcontent/uploads/2017/o8/SystemicTranslational-Review-peer-education.pdf.

Masa R, Chowa G, Sherraden M (2019). An evaluation of a school-based savings program and its effect on sexual risk 
Safitri et al./ Peer-Based Intervention on Prevention Behavior of Unwanted Pregnancy

behaviors and victimization among young Ghanaians. Youth Soc. 52(7): 1083-1106. https://doi.org/10.1177/oo44118X18824730.

Mezey G, Meyer D, Robinson F, Bonell C, Campbell R, Gillard S, Jordan P, et al. (2015). Developing and piloting a peer mentoring intervention to reduce teenage pregnancy in looked-after children and care leavers: An exploratory randomised controlled trial. Health Technol Assess. https://doi.org/10.3310/hta19850.

Mmbaga EJ, Kajula L, Aarø LE, Kilonzo M, Wubs AG, Eggers SM, De Vries H, et al.(2017). Effect of the PREPARE intervention on sexual initiation and condom use among adolescents aged 12-14: A cluster randomised controlled trial in Dar es Salaam, Tanzania. BMC Public Health, 17(1). https://doi.org/10.1186/s12889-017-4245-4.

Morales A, Espada JP, Orgilés M (2016). A 1-year follow-up evaluation of a sexual-health education program for Spanish adolescents compared with a well-established program. Eur J Public Health. 26(1): 35-41. https://doi.org/10.1093/eurpub/ckvo74.

Okonofua FE, Coplan P, Collins S, Oronsaye F, Ogunsakin D, Ogonor JT, Kaufman JA, et al. (2003). Impact of an intervention to improvetreatmentseeking behavior and prevent sexually transmitted diseases among Nigerian youths. Int J Infect Dis. 7(1): 61-73. https://doi.org/10.1016/S1201-9712(o3)90044-0.

Oman RF, Vesely SK, Green J, ClementsNolle K, Lu M (2018). Adolescent pregnancy prevention among youths living in group care homes: A cluster randomized controlled trial. Am J Public Health. https://doi.org/10.2105/AJPH.2017.304126.
Peskin MF, Coyle KK, Anderson PM, Laris BA, Glassman JR, Franks HM, Thiel MA, et al. (2019). Replication of It's Your Game Keep It Real! in Southeast Texas. J Prim Prev. 40(3): 297-323. https://doi.org/10.1007/s10935-019o0549-0.

Raidoo S, Kaneshiro B (2017). Contraception counseling for adolescents. In Curr Opin Obstet Gynecol. 29(5):310315. https://doi.org/10.1097/GCO.oo00000000000390.

Saad A, Lekhraj R, Sabitu K, AbdulRahman $\mathrm{H}$, Awaisu A, AbuSamah B, Ibrahim A (2012). An HIV-STI risk reduction program among undergraduate students at a northern Nigerian university: A randomized controlled field trial. J Public Health (Germany). 20(5): 549-559. https://doi.org/10.1007/s10389-012-0491-1.

Sarnquist C, Sinclair J, Omondi MB, Langat N, Paiva L, Halpern-Felsher B, Golden $\mathrm{NH}$, et al. (2017). Evidence that classroom-based behavioral interventions reduce pregnancy-related school dropout among Nairobi Adolescents. Health Educ Behav, 44(2): 297-303. https://doi.org/10.1177/10901981166 57777.

Sherman SG, Sutcliffe C, Srirojn B, Latkin CA, Aramratanna A, Celentano DD (2009). Evaluation of a peer network intervention trial among young methamphetamine users in Chiang Mai, Thailand. Soc Sci Med, 68(1): 69-79.https://doi.org/10.1016/j.socscimed.2 008.09.061.

Sieving RE, McMorris BJ, Beckman KJ, Pettingell SL, Secor-Turner M, Kugler K, Garwick AW, et al. (2011). Prime time: 12-month sexual health outcomes of a clinic-based intervention to prevent pregnancy risk behaviors. $\mathrm{J}$ Adolesc Health. https://doi.org/10.- 
Safitri et al./ Peer-Based Intervention on Prevention Behavior of Unwanted Pregnancy

1016/j.jadohealth.2010.12.002.

Sieving RE, McRee AL, Secor-Turner M, Garwick AW, Bearinger LH, Beckman KJ, McMorris BJ, et al. (2014). Prime Time: Long-Term Sexual Health Outcomes of a Clinic Linked Intervention. Perspect Sex Reprod Health, 46(2): 91-100. https://doi.org/10.1363/46e0914 .

Sieving RE, McRee AL, McMorris BJ, Beckman KJ, Pettingell SL, Bearinger LH, Garwick AW, et al. (2013). Prime time: Sexual health outcomes at 24 months for a clinic-linked intervention to Prevent pregnancy risk behavior. JAMA Pediatrics. 167(4):333-40. https://doi.org/10.1001/jamapediatrics.2013.1089.

Stephenson J, Strange V, Allen E, Copas A, Johnson A, Bonell C, Babiker A, et al. (2008). The long-term effects of a peer-led sex education programme (RIPPLE): A cluster randomised trial in schools in England. PLoS Medicine, 5(11): 1579-1590. https://doi.org/10.1371/journal.pmed.o050224.

Strange V, Allen E, Oakley A, Bonell C,
Johnson A, Stephenson J (2006). Integrating process with outcome data in a randomized controlled trial of sex education. Evaluation. 12(3): 330-352. https://doi.org/10.1177/1356389006069138.

Tobin KE, Kuramoto SJ, Davey-Rothwell MA, Latkin CA (2011). The STEP into Action study: A peer-based, personal risk network-focused HIV prevention intervention with injection drug users in Baltimore, Maryland. Addiction, 106(2): 366-375. https://doi.org/10.1111/j.1360-0443.2010.03146.x.

UNICEF (2012). Progress for Children: A report card on adolescent. Retrieved from https://www.unicef.org/publications/files/Progress_for_ChildrenNo._10_EN_04232012.pdf.

Wesche R, Kreager DA, Feinberg ME, Lefkowitz ES (2019). Peer Acceptance and Sexual Behaviors from Adolescence to Young Adulthood. J Youth Adolesc. 48, 996-1008 (2019). https://doi.org/10.1007/s10964-019-00991-7. 